\title{
Travelling Detectives.
}

\section{Twofold Mobility in the Appropriation of Crime Fiction in Interwar Germany}

Christian Huck, Kiel University

This is a post-peer-review, pre-copyedited version of an article published in Transfers. Interdisciplinary Journal of Mobility Studies (2.3, Winter 2012, pp.120-143). The definitive publisher-authenticated version is available online at: http://berghahn.publisher.ingentaconnect.com/content/berghahn/trans/2012/00000002/0 $0000003 / \operatorname{art00008.~}$

abstract: This article is concerned with travelling detectives in two different, but related senses. On the one hand, it considers the relevance of trains and other vehicles of mobility for detective fiction, both as a topic of fiction and a place of consumption. On the other hand, it registers that detective fiction has to 'travel' in a more abstract sense before the reading traveler can enjoy it. German publishers appropriated the genre, originally a nineteenthcentury American and British invention, at the beginning of the twentieth century. Based on contemporary observations by German cultural critics Walter Benjamin and Siegfried Kracauer, the essay examines German crime fiction dime novels from the interwar period, compares them to their American predecessors, and analyses their relationship to mobility and cultural transfer. The text argues that the spatial mobility of the fictional detective is only possible in a specific cultural environment to which the moving, but corporeally immobile reader has to be transferred imaginatively.

key words: train travel, dime novels, detective fiction, Weimar Republic, cultural transfer, mobility/immobility, appropriation

\section{Introduction}

On 1 June 1930, Walter Benjamin published a short essay in the literary supplement of the Frankfurter Zeitung; the text was entitled "Kriminalromane, auf Reisen," which at first glance refers to reading crime novels while the reader is travelling, but could also mean literally that crime novels are travelling. Benjamin writes: 
On the train, very few people read books which they have in their shelves at home, preferring to buy what presents itself to them at the last minute ... One knows the coins which one devotes to this offertory box commend one to the mercy of the boilergod which blazes through the night, the smoke-naiads which romp above the train and the judder-demon who is master of all lullabies. One knows them all from dreams, knows too the succession of mythic trials and dangers which commends itself to the zeitgeist as the 'railway journey,' an unfathomable flight across the sleeping thresholds of time and space ... Likes are cured by likes. Deadening one fear with another is our salvation. Between the freshly cut pages of crime novels one seeks the idle or, if you like, virgin feelings of trepidation which could help us overcome the archaic ones of the journey. ${ }^{1}$

According to Benjamin, the fear evoked by the frightening machinery of the train can only be allayed by the suspenseful excitement of reading those cheap thrills that are offered at the station bookstalls. Although the railway journey had lost its more obvious terrifying appeal, the sleep induced by the 'master of all lullabies' was still giving birth to nightmarish trials. Crime novels, Benjamin suggests, address a deep-seated fear that modern culture usually suppresses. The cultural analyst, consequently, can learn about the dreams and fears of the popular mind by reading those cultural products that address fears the ordinary reader might not even know about.

Clearly, Benjamin is interested in the first, more obvious meaning of his essay title, i. e. the reading of crime novels while travelling. He seems less interested in the significance of the fact that crime fiction has been on a journey, too: originally an Anglo-American invention, the genre of detective fiction, widely available at station bookstalls in the 1920s, did not come to Germany until the beginning of the twentieth century. However, there is a connection between these two forms of mobility. In order to recognize this connection, we will have to understand a third, fictional mobility: the mobility of the detective who becomes the central figure of crime fiction in the 1920s. Looking at vehicles of transport and popular fiction, this article is thus situated "at the intersection of communication and transportation technologies, both of which travel across space, whether virtually or physically."2

In the following, I will first elaborate on the habitual nexus between reading crime fiction and travelling on trains. Second, I analyze the extent to which those 'thresholds' that separate and connect the world of the reader from/to the world of fiction-i. e. book covers $^{3}$ - articulate, address and organize questions of mobility and cultural transfer. Last, I 
look more closely at the cultural origins of the detective genre, and how this genre has been appropriated in Germany. What I want to show is how the corporeal $\mathrm{im} / \mathrm{mobility}$ a traveler experiences during a railway ride is met by fictional forms of mobility, and why these fictional forms are based on acts of cultural transfer. As we will see, the appropriation of new technological developments elicits the appropriation of new cultural forms.

'Appropriation' means to 'make something one's own.' The process need not be a legal or economic one only. Appropriation means also the process of giving something alien to one's way of life (a material object, a technology, an idea or concept) a place within one's conceptual framework; to appropriate something means to find a proper - or rather: an appropriate, i. e. culturally acceptable — way of handling something. Often, appropriation becomes necessary when objects 'travel' from one culture to another, be this culture defined by region, gender, age, occupation or similar parameters. In the context of this essay, two forms of appropriation are especially relevant. On the one hand, appropriation describes the process through which a technology, the railway, previously used in industrial contexts only, is integrated into a general culture of travel. On the other hand, I understand 'appropriation' also to mean the process of shaping an alien form in order that it be more easily handled in another culture; appropriation, here, relates to processes of transcultural adaptation. ${ }^{4}$

Central to my analysis are German Groschenhefte (dime novels). ${ }^{5}$ These are neither interpreted according to traditional hermeneutic and/or semiotic procedures only, nor are they seen as representations of social structures only; they are understood as media, and consequently as "material-semiotic generative nodes," objects that through their materiality and meaning act as transformative agents. This means that, on the one hand, Groschenhefte are to be analyzed as semiotic formations whose meaning for the 'reader' derives not only from the written or graphic text but also from the materiality of the medium, that is to say a book's size, means of reproduction, font, paper, etc. The semantics of texts, here, are supplemented by a pragmatics of reading that considers the corporeal situatedness of the reader as well. ${ }^{7}$ On the other hand, the specific material features of the Groschenheft link it to broader technological, economic and material developments, so its forms of distribution and consumption must also be taken into consideration. Analyzing dime novels this way reveals how they not only represent aspects of mobility and cultural transfer, but are also present within broader developments of mobility and cultural transfer. 


\section{Travel Writing: Books for Travelers}

In a recent study, Christine Haug has shown how the rise of popular literature in the nineteenth century was closely connected to the mechanization of travel and the subsequent establishment of a network of station bookstalls. ${ }^{8}$ Haug emphasizes that the main motive for reading cited by early twentieth-century train travelers is not fear or angst, as Benjamin suggests, but boredom and dullness. Since its early nineteenth-century beginnings, rail travel had become a more comfortable and less frightening affair: "The ever-present fear of potential disaster remained [...] only until the railroad had become a part of normal everyday life. By the time Western Europe had culturally and psychically assimilated the railroad, that is, by the mid-Nineteenth Century, these anxieties had vanished." ${ }^{9}$ Whereas early travelers, as Wolfgang Schivelbusch's paradigmatic study convincingly argues, seemed to live in constant apprehension of "instant death to all upon the least accident happening," 10 later travelers were "enabled to relax in the railway carriage, and to sit in it without moving a muscle, without 'exertion' or any 'other passions'.,"11

The sole task of the later, 'relaxed' and 'passionless' traveler was to consult the timetable, buy a ticket and board the right train at the right time; the twentieth-century train ride, at least in the Western world, took place in warm, dry and well-lit compartments. Train rides were no longer the thrilling adventure they had been in the early years of their establishment, which might have produced those nightmares of 'mythic trials and dangers' that Benjamin refers to. If there were any dangers to be met on an early twentieth-century train, these resulted from criminal activities of fellow travelers. ${ }^{12}$ Half a century after its widespread adoption, the technology of the railway had been appropriated; it was no longer a fearful foreign element, but something to use according to one's own cultural maps of meaning; one knew what to expect. The acceleration of the technological machine only contributed to the experience of social and emotional disengagement. The constantly changing landscapes outside the window did no more to facilitate perceptual engagement than the constantly changing strangers sharing one's compartment, with their various social and regional backgrounds, did to encourage engaging conversations. ${ }^{13}$

Reading became a way out of this im/mobile disengagement, and fought boredom as well as the embarrassment of being bored in the company of strangers. ${ }^{14}$ And what better to fight boredom with than suspenseful entertainment, especially in the form of crime fiction? Consequently, crime and detective writing, especially in the short, cheap and handy form of the dime novel, became the main genre sold at station bookstalls. ${ }^{15}$ The genre became especially prominent in the 1920 s, rivaled by similarly structured adventure stories only. 
Whereas travelers had previously read either travel guides, feuilletonistic infotainment or repackaged classics, often part of specialized 'railway series,' the early twentieth century saw a rise of contemporary fictional works on the shelves of station bookstalls. ${ }^{16}$

The traveler had the need, and the media suggested what to read. The discursive nexus between popular fiction, especially crime fiction, and (holiday) travel was robust and common when Benjamin published his article in 1930. A striking example illustrating this connection is the Literarische Welt, the leading literary weekly paper of the Weimar Republic. Scanning the relevant volumes of the paper, one discovers that popular fiction in general, and detective fiction in particular, is - usually-more or less completely ignored. However, the special summer editions regularly offered at the beginning of each holiday season by Literarische Welt and similar papers reveal a drastically changed situation. Suddenly, popular fiction came to the fore, and with it the experience of travelling. The literary supplement to the Frankfurter Zeitung, for example, illustrates its special edition of June 7, 1931, with a relaxed, smoking reader and a steaming railway (fig. 1); both the machine stopping at the station and the vacationer reading a book 'let off steam'; both are freed, for once, from their involvement in technological and economic contexts. When travelling, this seems to suggest, the literary standards that exclude crime fiction can, for once, be dropped.
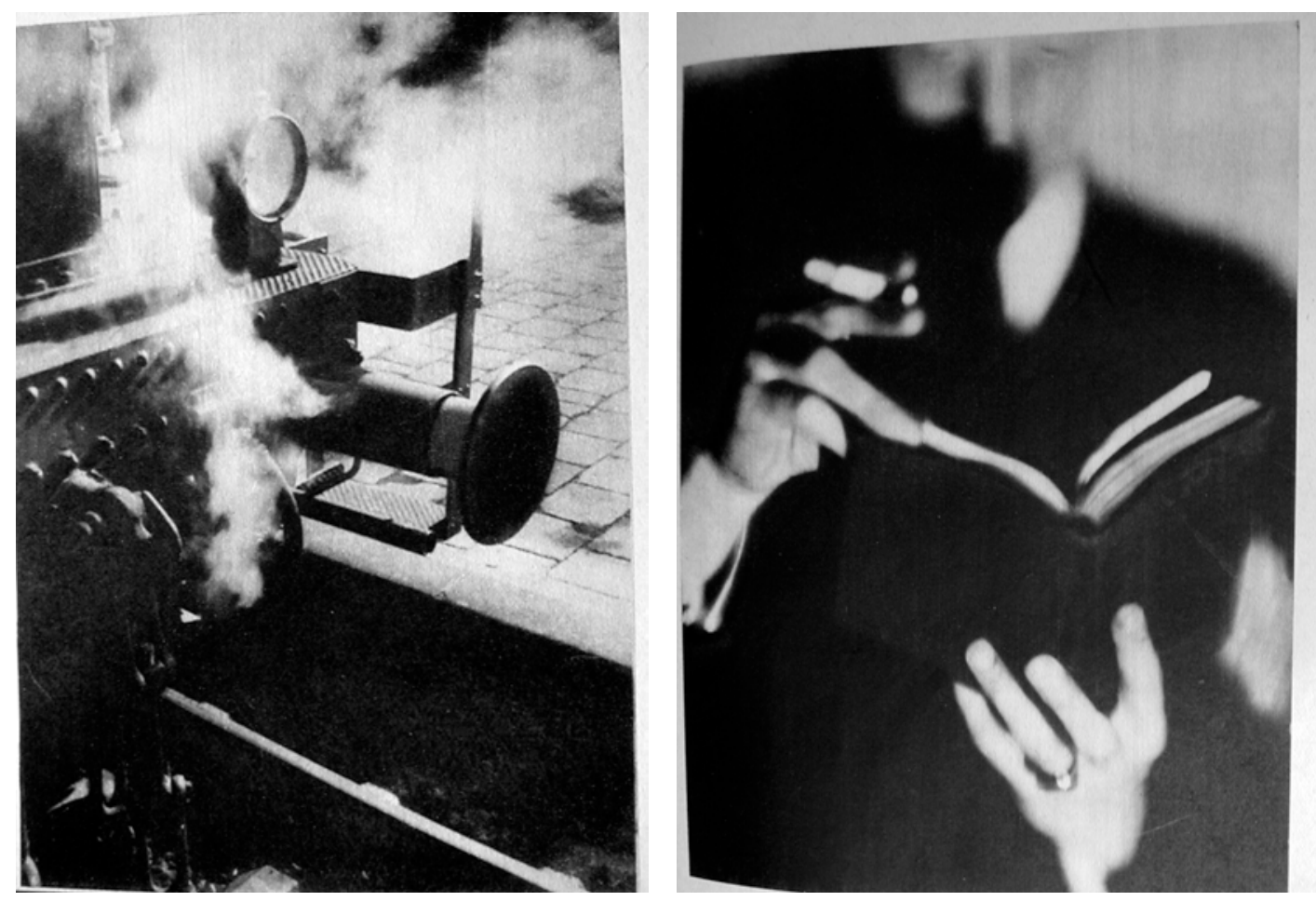

Fig. 1: Images from Literaturblatt der Frankfurter Zeitung, 7 June 1931, page 1 
The special edition of the Literarische Welt of June 10, 1932, was a double issue specifically devoted to 'Entertainment and Travel Literature' ('Unterhaltungs- und Reiseliteratur'). The front-page editorial is concerned with the role and function of such literature, and it mentions crime and detective fiction in particular; while the editorial affirms the widespread notion that travel literature is a trivial genre, the usefulness of the genre for specific, relaxing purposes is not denied. Moreover, the special edition not only discusses such writing; it even offers the first installment of a serialized crime novel. Such an informative and creative treatment of the genre attracts advertisements for crime fiction as well: "No Journey/Trip without a Goldmann Book!" (“Keine Reise ohne Goldmannbuch!"), one ad proclaims. Crime fiction here is linked to a realm beyond the serious demands of economy, politics, art, etc. that usually dominate the pages of quality papers; while popular literature is normally barred from the bürgerliche world, the travelling seems to legitimize the consumption of such forms of entertainment.

One of the rare half-page advertisements found in Literarische Welt promotes Goldmann's bestsellers by Edgar Wallace. Wallace was one of the few crime fiction writers to whom the feuilletons (arts and culture section of quality newspapers) of the Weimar Republic paid any attention. Wallace was the most advertised - and, as the ads constantly reiterated, best-selling - crime fiction writer of his time. It is important to note here that I take it to be no coincidence that the most famous and most successful crime fiction writer of the Weimar Republic was of English provenance. While this continues a long tradition of associating detective fiction and popular literature in general with Britain and the USA, ${ }^{17}$ it is not only the Britishness of the author Edgar Wallace that is identified with crime fiction. It is above all the figure of the detective who, for the German audiences of the time, could only be thought of as being British or American.

As early as 1920, at least one important cinema critic had become fed up with the stereotypical depiction of the detective on German cinema screens and demanded a more thorough appropriation of Anglo-American models. In an article entitled "What I don't want to see on the cinema screen anymore," Norbert Jacques asks that the detective at least be stripped of his Anglo-American accessories: "When will a director be brave enough to take the pipe out of the all-knowing detective's mouth, to take the jockey cap off and pull the checkered knickerbockers down?"18 Looking back upon this period from his postwar exile, Siegfried Kracauer, arguably the most astute observer of German interwar culture, writes: "It is noteworthy that, while the French and Americans succeeded in creating a national counterpart of Conan Doyle's archetype, the Germans always conceived of the great detective as an English character." ${ }^{\prime 19}$ As American authors were just as important in creating the 
archetypical detective, it is probably incorrect to attribute the detective to England, as Kracauer does; but he is right in that the Germans failed to create German detectives.

While Walter Benjamin rightly emphasized the link between crime fiction and (railroad) travel, there are two points to which he seems to have paid little attention in his above-mentioned analysis, and on which I would now like to focus. On the one hand, Benjamin does not seem to consider that the reader's imaginary journey might be founded upon the immobility of the body and the resulting boredom, rather than on the experience of fear. On the other hand, Benjamin seems to be oblivious to the return of the 'thresholds of time and space,' assumed to have been annihilated by technological mobility, as important cultural borders within the fictional world. The reader does not wander to just any place, nor to no place, but specifically to England and the USA. The mobility of a globalizing modernity is not without specific localities.

\section{Images of Mobility and Immobility: Moving Book Covers}

Station bookstalls were at the peak of their development in the 1920s: they were widespread and professionally organized. Book covers became a central element in the marketing of the books competing for the prospective traveler's attention. ${ }^{20}$ When searching for the right reading material, images of mobility are the first thing the potential reader catches sight of. Beyond those series explicitly addressing the tradition of reading on trains, ${ }^{21}$ images of technologically accelerated means of transport, i. e. trains, cars, busses, planes, and boats, are constantly displayed.

Many dime novel book covers show various vehicles at full speed (fig. 2). The vehicles are captured in the image, stalled and made available for the reader; the image arrests movement obviously in progress, retaining an energy that the narrative in the book promises to release. While cars, boats and planes appear to address the individual mobility so important to the detective, trains and coaches link mobility to a travel experience more familiar to readers. ${ }^{22}$ On the cover of "Autobus $R-27$ " (fig. 2) the realities of travel, represented by the photographic index of a motorbus, are superimposed by the crooked specter of a gun-toting criminal, his left hand cramped into a claw, pinching for the possessions of innocent travelers. Travelling, these covers suggest, is dangerous and full of action: not because of the uncontrollable contingencies of technological machinery, but because of the actions of fellow humans who appropriate this machinery in the service of their own nefarious ends. 

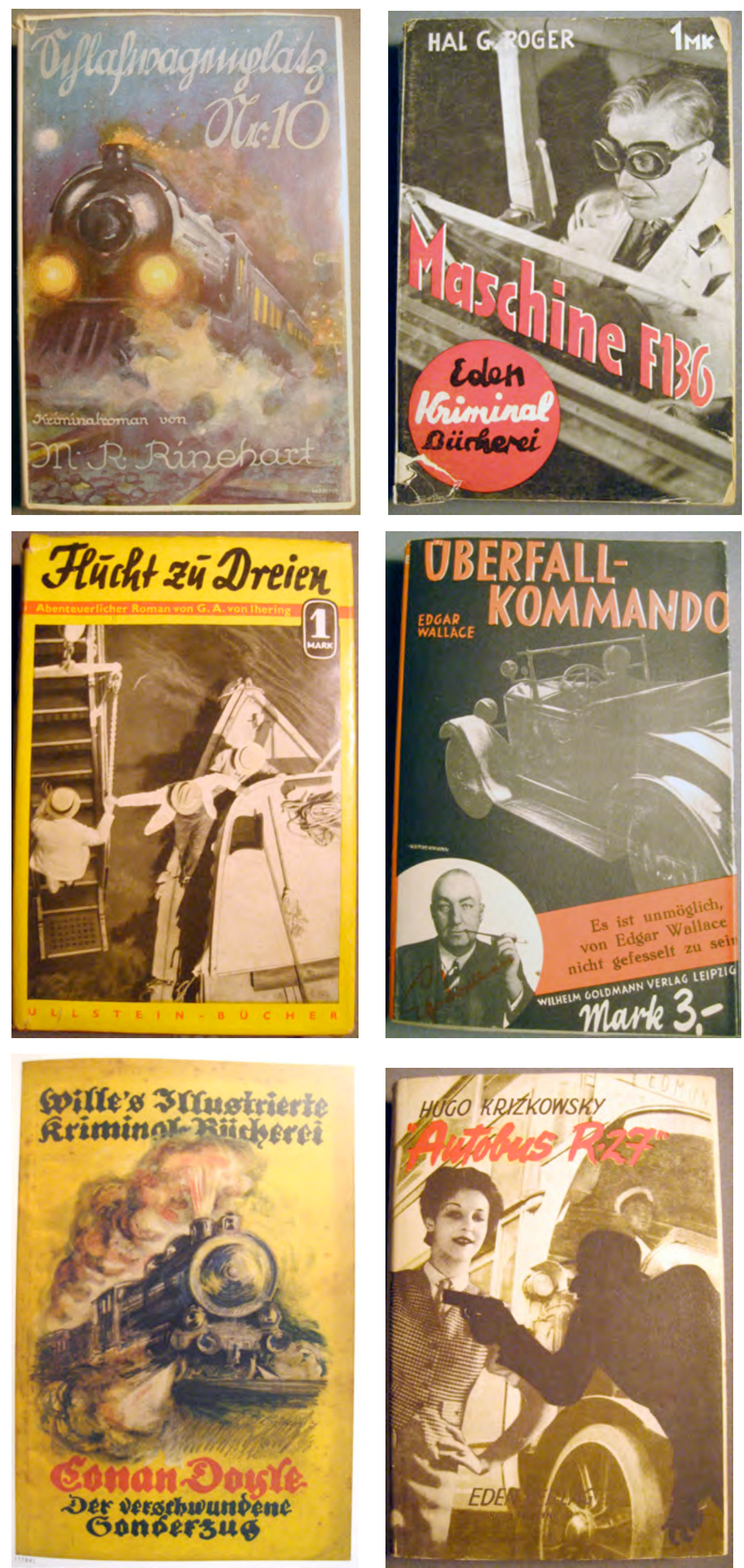

Fig. 2: Dime Novel Covers from the 1920s and 1930s 
Mobility is not only addressed by the images on the cover but also by the book titles, displayed in captivating fonts. Most characters seem to be either fleeing from or chasing someone or something: there are Henry MacDonald's Spione auf der Flucht (Spies on the Run; 1932), Marcus Magill's Mörder auf voller Flucht (Murderer on the Run; 1938), Julia Jobst's Die wilde Jagd (The Wild Chase; 1919) and many more. The stories promise chases across rooftops, streets, rivers and tracks. ${ }^{23}$

But what is the effect of this pronounced mobility? Various blurbs printed on the covers give an answer to this question as well: "Never did I feel a train journey pass so quickly as when accompanied by the latest volume by Edgar Wallace. I did not look up for hours." 24 And why did the reader not move once? "Every page explodes with action; every chapter is a wild chase through a world full of adventures. ${ }^{25}$ The reader, corporeally fixed, cannot help but follow the chase: "When reading a Wallace novel one is inevitably swept away by a stirring storm of dramatic events." ${ }^{26}$ Indeed, the fictional events the reader is forced to follow become his reality: "One does not simply read Wallace—one experiences Wallace!",27

The vehicles on the covers are propelled by modern technology; the protagonists of the stories use these vehicles to move through the fictional world; and the readers are (meant to be) moved by the suspenseful action of these imagined realities. Will the innocent escape? Will the detective catch the culprit? However, amidst all this mobility, something remains fixed, immobile: the book "which ties the reader to his seat until he has finished the final pages" ${ }^{28}$ leaves no room for escape. Numerous covers and advertising slogans repeat the claim that the books in questions are 'fesselnd': this means, figuratively, that they 'captivate' the reader's cognitive attention, but in a literal sense it also means that they 'tie up' the reader corporeally. Every Wallace publication and advertisement is adorned with the words "It is impossible not to feel 'captivated/tied up' by Wallace!" However, the forced immobility of the body becomes a voluntary pleasure; the reader is reconciled with the unfamiliar experience of having to stay put. As long as the mind is swept away, the body does not even want to move. Because of this, detective novels can be said to have been consumed in order "to pass the time (of waiting, while being carried) on ... trains.",29

To draw a first conclusion: crime fiction dime novels did not become so successful only because they were a means to fight fire with fire, i. e. because the cheap thrills of the dime novel could make the reader forget the more profound "shocks" ${ }^{30}$ caused by the acceleration of his life-world. While it might be true that modernity is marked by technological acceleration, as Paul Virilio and many others have argued, ${ }^{31}$ it is often 
overlooked that ordinary people's experience of modernity is at least as much dominated by the experience of immobility. If "speed is the single new pleasure invented by modernity,",32 as Enda Duffy claims, then waiting, as Samuel Beckett has shown, is what modernity brings to those beyond the elite.

The train, more than any other means of transportation, restricts the freedom of travelling by sea or by air or even on streets or canals; ${ }^{33}$ the dependence on the track and the need to change trains demand great efforts of bureaucratic synchronization and orderly behavior. In a short chapter on "Railway Navigation and Incarceration," Michel de Certeau claims that "only a rationalized cell travels." ${ }^{34}$ Sitting and waiting became a common new experience: waiting for trains, busses and trams, sitting still on these vehicles, and again in waiting rooms of organizations, agencies, doctors, etc. The rationalization of bureaucratic organizations might have sped up proceedings, but it also made strict timing necessary; consequently, the clients of such organizations were made to wait and forced into passivity, so that the (hierarchically superior) professionals would not lose time. ${ }^{35}$ What was ostensibly a new mobility is experienced as immobility: "Immobile inside the train, seeing immobile things slip by. What is happening? Nothing is moving inside or outside the train. The unchanging traveller is pigeonholed, numbered, and regulated in the grid of the railway car." 36 Instead of a fear of technology or speed, the insufferableness of the experience of waiting motivates reading; the 'mythic trials and dangers' that Benjamin finds lurking behind train travel are indeed those of the waiting room: isolation, distance, contingency, dependency, powerlessness. $^{37}$

Amidst the acceleration of machines, transportation and communication, the dime novel became a means to appease the increasingly im/mobile reader: "The reader who mentally escapes into the universe of a principal character of a book is ... mobile without necessarily moving." ${ }^{38}$ While detective novels might have been a guilty holiday pleasure for the bürgerliche reader of Literarische Welt, it became a daily necessity for the average reader who populated trains and waiting rooms. It is notoriously difficult to determine the readership of popular literature, because there are hardly any records of actual, empirical readers. Despite this, the many voices of 1920s critics suggest a mostly male, juvenile readership consisting of pupils, young apprentices and office workers ${ }^{39}$ - exactly the ones that had to accommodate the habitus of corporeal immobility in the new office and assembly line working world and as clients of bureaucratic organizations. ${ }^{40}$ Whereas romances from Ullstein and other publishers using the station bookstalls for dissemination were addressed to female apprentices and office workers, crime and detective fiction was catering to a predominantly male readership. ${ }^{41}$ 
With the rise of commuting and literacy rates beyond ninety percent, reading on trains had become a common pursuit by the 1920s. Whereas the quality papers analyzed above connected travel with holiday rides, the more mundane commuting had become the most common use of transportation in the Weimar Republic, and two-thirds of all commuters used public transport. ${ }^{42}$ While these readers experienced mobility as immobility on trains, omnibuses and trams, the dime novel detectives (and villains) sped away using cars, planes and boats - transportation the apprentice could not afford. Despite the burden of post-war reparation on the Deutsche Reichsbahn, the railway was still the most dominant form of travel in the Weimar Republic, increasingly supplemented by the autobus. ${ }^{43}$ More individual forms of travel were unavailable to most: by one estimate, only one of 147 Germans owned a car by the end of the 1920s. ${ }^{44}$ The concurrence embodied by the automobile of client and professional, passenger and driver, and the fuller experience of speed it thereby created, was still beyond the reach of most—at least in reality.

\section{The Need to Anglicize the Detective}

Fictions of mobility can transport the mind and leave the immobile body behind. As we saw above, the books tend to take the reader to the USA and to Great Britain, or at least to some Anglo-American realm. A sample of 1715 authors who published detective and crime fiction in Germany between 1918 and 1939 gives a more detailed picture. ${ }^{45}$ For one, no more than forty percent of all publications can be attributed to German authors. Of the remaining approximately 8,000 volumes written by German authors, not even half are published under a German name. More than 4,100 volumes are published either under an anglicized pseudonym or purported to be chronicles of an Anglo-American detective.

For example, 566 dime novels document the adventures of one Tom Shark, as recorded by his assistant Pitt Strong - a pseudonym of the German author Elisabeth von Aspern. Such pseudonyms were pervasive. More importantly, not only the authors but also the protagonists are tinged with Anglo-American flavor: the most prominent fictional characters on the crime fiction market of the time, apart from the aforementioned Tom Shark, carry names like John Kling, Harry Piel or Frank Allen. Even in rare cases in which neither correspondent nor protagonist have an Anglo-American flavor, the setting motivates a mental journey: Walter Ludolf Gebauer reports the adventures of Detective Frank, who, judging by his name, could be German; but his novel is called Der Mann aus der Bowery (The Man from the Bowery; 1938). If in fact neither author, protagonist, nor book title claims AngloAmerican provenance, the cover image or blurb often gives a nudge in the right direction. On 
the cover of C. F. Gregg's novel Der Mann auf dem Autobus (The Man on the Autobus; 1935) we detect the silhouette of an English policeman, and on the cover of Louis Vetter's Unheimliche Gegner (Uncanny Opponents; 1935) we read: "On a dark road close to Pentonville prison",46.

Detective fiction - especially those stories told in cheap and handy dime novels, sold at station bookstalls and enabling, through their material form alone, "a more casual and more ambulatory reading" ${ }^{47}$ — takes the reader on a journey: the names of authors and protagonists as well as visual and textual signifiers virtually transfer the reader to another cultural realm. This Anglo-American realm seems to offer possibilities of storytelling that do not exist in a purely German context. Detective novels whose authors, protagonists or settings do not refer to an Anglo-American context are clearly in the minority. In the following, I will explain why German publishers went to such great lengths to give their crime fiction publications an Anglo-American touch.

\section{Nick Carter and the Total Mobility of the Dime Novel Detective}

Many of the early detectives were creations of English and American authors, and international metropolises like London, New York or Chicago were their turf. Of course, these authors were participating in a much older European tradition of writing about crime, but the installation of the detective at the heart of the story was their innovation. As Kracauer writes in the above-mentioned quote, most countries had little problem transplanting the figure of the detective into their own culture and appropriating the detective. (Poe's detective Dupin, after all, was French and worked in Paris.) However, the appropriation of detective fiction for German readers had to stop short of changing the provenance of the stories.

The Groschenhefte cited above follow a distinctly American tradition. Between 1860 and 1880, most American dime novels told frontier and western stories. When city life succeeded the experience of the frontier towards the end of the century, urban crime became a central topic, and the detective supplanted the cowboy. ${ }^{48}$ At the beginning of the twentieth century, German publishers began to look to the US for innovative formats, and one of the first finders was Alwin Eichler, a young publisher who had done part of his apprenticeship in the USA. In 1903, he returned to Germany, but not without having acquired the copyright for such famous American dime novel series as Buffalo Bill and Nick Carter. ${ }^{49}$ In 1905, he began publishing translations of these series in German and other European languages. Especially the Nick Carter series proved an immediate success, selling up to 80,000 copies a week. 
Nick Carter is a paradigmatic example for the early phase of appropriation of the American detective in Germany. Translations of American originals, together with relatively loose adaptations of other American and British characters dominated the market until the First World War; ${ }^{50}$ the German inventions of the time did not seem capable of rivaling their success. Following the success of the free-ranging and wholly independent cowboys of earlier tales, the detective became a modern sign of global mobility. ${ }^{51}$

Carter was the ideal candidate to travel from the USA to Germany. He had proven in many stories that he could solve cases not only in all parts of the USA, but in virtually every corner of the world. Necessary for such mobility is the detective's mastery of disguise, one of the most striking features of Nick Carter. ${ }^{52}$ In order to go everywhere he wants, the detective has to be able to become whoever he wants. Carter mainly works in New York, a cosmopolitan world in miniature, but his liberation from recognition and his ability to adopt any personality at will allows him to investigate in every corner of the USA, easily accessible by the trains he uses frequently and in almost every episode, and which were connecting the whole country since the 1870s. At a time when the railway became a "symbol of economic expansionism and man's technological triumph over nature,"53 Carter used the new technology to triumph over those who misappropriated economic opportunities in a mobile society. The USA, however, did not remain the limit, and Carter used various forms of transport to travel the entire globe.

Geographical mobility is supplemented by an ability to move within different social spheres: Carter has little problem behaving appropriately among the upper classes aboard a cruise ship or in the saloons of the Wild West. ${ }^{54}$ His father taught him foreign languages and local customs so that he could remain undetected when undercover in a foreign country. Wherever Carter went, he could employ the same cognitive and physical abilities to outsmart and overpower his criminal opponents: competence in reading signs, deducing and interviewing, but also prowess at shooting, fighting and Houdini-like escaping.

A completely mobile detective, travelling the entire world, versed in various languages and adaptable to all classes, races, sexes and genders, became the ideal candidate to travel to Germany in the form of a new publication. ${ }^{55}$ The reader on board a German train, in order to be swept mentally from his fixed body, reaches for a dime novel featuring a detective who constantly goes wherever he wants or needs to go; the reading traveler is probably en route to his same old work place at this moment; but where the detective goes, there is action. As the detective slips into his disguise, the reader is invited to identify with the protagonist, i. e. to 
imagine himself in the shoes of the detective and to experience other, more exciting mobilities.

Despite the worldwide success of Nick Carter, German publishing tactics changed after the First World War. The method of buying up copyrights, or of simply adapting existing characters, was not resumed. Instead, the readers demanded localized versions and a whole variety of German publishing houses started issuing their own detective series. While these were written in Germany, by German authors, in the German language, they-as we saw above - nonetheless continued to give the impression that they were of Anglo-American provenance. After translating and adapting came a third mode of appropriation: reimagining. While other European countries like France took the chance to create their own super-mobile, super-disguised detective-villains (Lupin, Fantômas), detective series insinuating an AngloAmerican provenance dominated the interwar market in Germany. Why it was still necessary even for (almost) completely German detectives to create an Anglo-American impression is the subject of the following, concluding section.

\section{Exemplary Mobility: Tom Shark, the American German}

Tom Shark represents what seems to be the final step in the process of localizing an American genre, but even here its original provenance is not obscured. ${ }^{56}$ The publisher claims in an apparently handwritten, authenticating preface that Tom Shark has turned his back on the USA, where he has spent the early parts of his life, to return to his original hometown, Berlin. ${ }^{57}$ While the detective comes closer to the world of the reader, he maintains a link to the Anglo-American culture from which he comes. From his Berlin headquarters, Shark solves various crimes all over the world, always accompanied by his friend Dr. Pitt Strong, who, mimicking Holmes' Dr. Watson, recounts these adventures. The stories are filled with references to German localities, goods and customs, but Shark's cool demeanor remains American. Shark and Strong enjoy a German brandy called Asbach Uralt, but keep their butler Bill. Repeatedly, Shark and Strong's language (German) is interspersed with AmericanEnglish exclamations: "Damned!”, "Well, ...”, “All devils...!"

Shark, like his American predecessor Nick Carter, is not only a master of disguise but also extremely mobile. In almost every story, Shark and Strong don a new costume that allows them to move freely. Questions of mobility are often addressed right from the beginning. Every story opens with a small drawing that sets the tone for the rest of the story; more often than not, these images depict icons of mobility, i. e. cars, motorbikes, trains, trams, boats and planes. Similarly, many of the book covers conjure up notions of mobility (figs. 3 
and 4). While trains or other passenger-oriented means of transport (ships, airplanes) are often the vehicle of choice in reaching a crime site, the graphic images show those forms of individual mobility that are out of reach for most readers: private planes, cars and motorbikes. (Shark drives a Maybach convertible six-seater with silk curtains.) Again, the images arrest an action precisely at its peak of kinetic energy: the motion of the driver falling off his motorbike, the satchel in midair and the people sliding down the railway embankment will continue — only we do not know how and where to. But move they must (fig. 4).
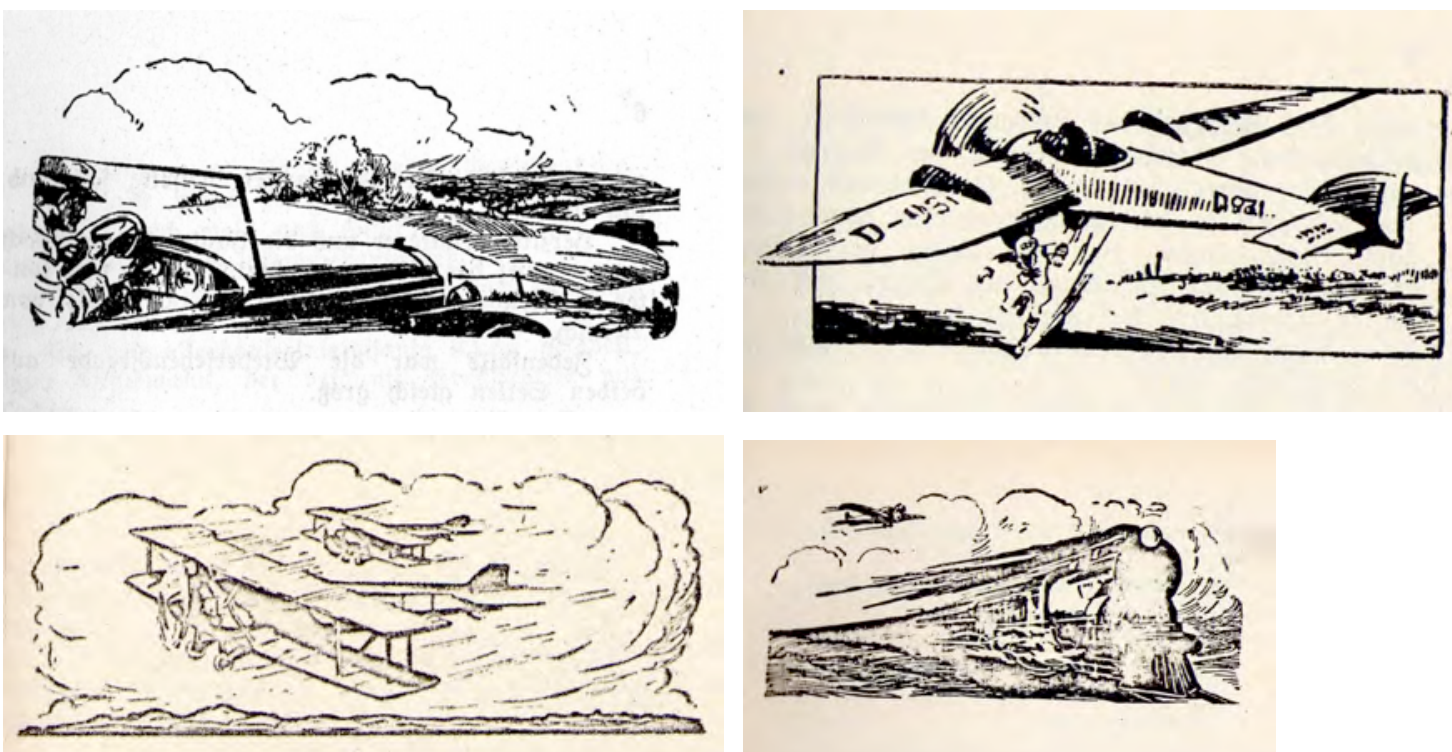

Fig. 3: Images from the opening pages of the Tom Shark series, nos. 8, 38, 119, 258.
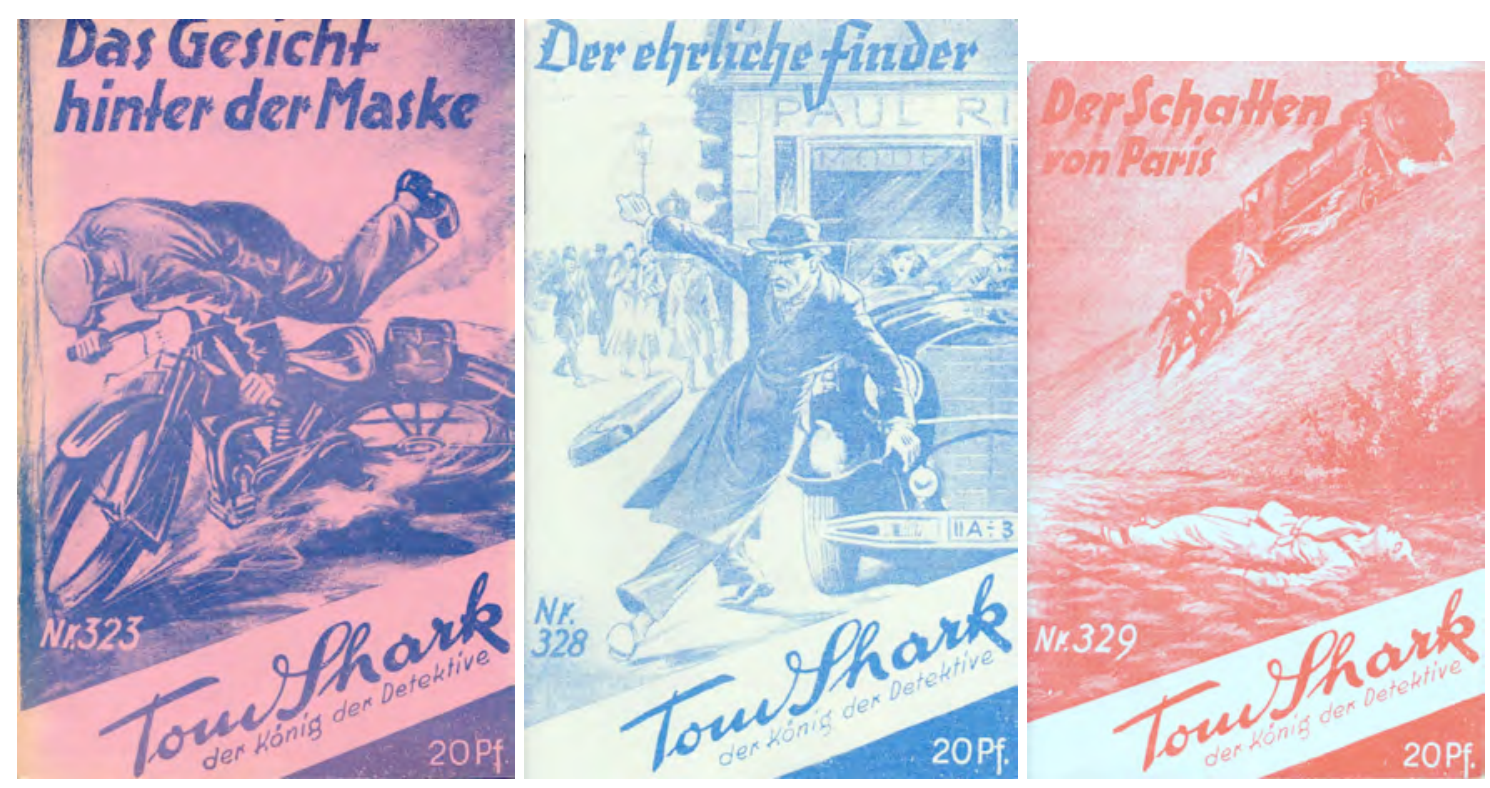

Fig. 4: Book covers from the Tom Shark series, nos. 323, 328, 329. 
Throughout the stories, Shark and Strong are constantly on the move. While one portion of the Shark-stories uses technologies of transport only to get to the crime scene, another part sees the detective exchange public means of transport for more individual, exciting and spectacular ones: car chases, airborne fights and boat races are a common staple of their adventures. Whereas avant-garde and elite literatures of the time searched for new stylistic devices to express the experience of velocity ${ }^{58}$ popular literature represented new forms of mobility in a more relaxed and affirmative manner, at least in the 1920s when the first controversies about the car and its dangers had somewhat withered. The detective uses the technologies of mobility in order to keep society stable.

As we have seen, Shark is of German origin, and while he often helps out his friend Inspector Brown from Scotland Yard in London, many of his adventures are situated in Germany — at least until the Reichsschriftumkammer ordered a crime-free (Nazi) Germany. ${ }^{59}$ In many ways, therefore, Shark is a German detective; but nonetheless, the publishers invent an American interlude to make the detective's adventures more credible. The question is: why? The image conjured up by Shark's American background, the American names and English-language interjections, have little to do with transporting the reader to actual America; indeed, Shark and Strong hardly ever go there, nor do they talk much about the USA, let alone admire the country. The function of Shark's American touch, then, is not to link him to the actual United States of America. Instead, the fictional realm evoked insinuates specifically Anglo-American rules of play, and under these rules the stories can unfold-even in Germany. It is these rules of fictional play that are so markedly different in 'Germany' than in 'Anglo-America' - the one set of rules allows mobility, the other does not.

To understand these rules it is useful to return to Kracauer's acknowledgement of the missing German detective:

It is noteworthy that, while the French and Americans succeeded in creating a national counterpart of Conan Doyle's archetype, the Germans always conceived of the great detective as an English character. This may be explained by the dependence of the classic detective upon liberal democracy. He, the single-handed sleuth who makes reason destroy the spider webs of irrational powers and decency triumph over dark instincts, is the predestined hero of a civilized world which believes in the blessings of enlightenment and individual freedom ... Since the Germans had never developed a democratic regime, they were not in a position to engender a native version of Sherlock Holmes. ${ }^{60}$ 
Kracauer's politically motivated assessment points in the right direction: looking for clues in pre-War German culture that lead to fascism, he finds that Germany's failure to establish more than a superficial, unstable form of liberal democracy renders impossible a home-grown detective. Though Kracauer's traditional association of the detective with reason and enlightenment reiterates the faulty identification of the detective with Sherlock Holmes, its bourgeois British version, Kracauer's emphasis on individual freedom might help to solve the conundrum of the Anglicized and mobilized German detective.

Even though this might come as a surprise after all that has been said so far, German crime stories, written by German authors with German settings and German investigators, did exist in the interwar period. There was a long tradition of crime writing in nineteenth-century Germany for twentieth-century publications to build upon; ${ }^{61}$ some publishers even specialized in such publications. In many respects these narratives are similar to those of Tom Shark and like publications: people deduce, interview, (sometimes) fight and finally solve a crime. The powers of reason and deduction are not alien to German investigators. In one respect, however, the difference is essential: in almost every issue of nearly three hundred volumes in the series Kleine Kriminal-Bücher (Little Crime Books, 1919-1924), each crime is solved by a different investigator. Unlike Nick Carter or Tom Shark, who solve hundreds, if not thousands of different cases, the characters that solve the crimes of the Kleine Kriminal-Bücher always live in the very cultural context in which the crimes take place. Often, a relative or a friend of the injured party solves the mystery.

German investigators can only do one-off jobs because they need the relevant knowledge of places and people to solve the crime; they need to know about traditions. It is as though a deep embeddedness within cultural webs of meaning is considered to be the basis of a typically 'German' way of solving a crime; their investigative skills cannot transcend their cultural origins, and they are spent in their exchange for a solution. The German detective, as a contemporary observer notes, is a "static" detective investigating family matters. ${ }^{62}$ The serial detective, whose powers can be applied repeatedly, remained an 'Anglo-American' phenomenon. Only the serial detective has to be mobile and vice-versa: only the mobile detective can be serial. While the serial, mobile 'Anglo-American' detective is able to appropriate every new situation, the one-off, immobile 'German' detective is unable to make another situation his own.

That the detective can investigate anywhere is a specific achievement of the popular dime-novel detective. The serial dime-novel detectives can be employed again and again: after their job is done, they are freed for new appointments. ${ }^{63}$ Indifferent to context and 
history, the anglicized German detectives follow the 'Anglo-American' way of detection. This 'Anglo-American' way is not based on embedded, cultural forms of knowledge, but on pragmatic ways of solving new problems as they come along. These are qualities of a progressive state of mind that imagines itself to be always on the brink of something new. Such a pragmatic state of mind is considered, at least by German readers, to be 'AngloAmerican.' A state of mind emphasizing the certainties of a local past over the entropies of an open future, seeking to find the solution to a case in its history, is considered, at least by German readers, to be 'German.'

Ever since Goethe (“Amerika, du hast es besser ..."), Germans admired and derided America in equal measures for being what they themselves are not: free-free of cultural baggage, and therefore free to move and free to act. Such schizophrenic forms of othering, of seeing in others exactly that which you want or do not want for yourself, was especially prominent during the Weimar Republic, where various societal forces fought over Germany's future. The debate about America was mainly a debate about Germany. Theodor Lüddecke, who coined the term 'Americanism' in the 1920s, sums up the American character as energetic, dynamic, active and open to the future. ${ }^{64}$ For Kracauer, however, the mobility of the detective is a sign of his loss of culture: "The emphasis on internationality — which does not overcome the creatural and therefore confined togetherness, but deliberately ignores it - is merely a sign of a partial failure to recognize the conditionality of reality and of the transformation of reality into spatial configurations." ${ }^{, 65}$ For Kracauer, the easy appropriation of alien contexts is nothing more but a superficial costume- - a fiction.

While the German Bildungsbürgertum ('educated bourgeoisie') heavily protested the introduction of American forms of entertainment (film, music, dance), the widespread demand for these products challenged traditional cultural hierarchies: the debate about (the threat of) 'Americanization' was also a debate about the place of popular culture. ${ }^{66}$ The popular dime novels managed to address the situation of the 'salaried masses' more directly than other forms of literature: ${ }^{67}$ while new systems of transport facilitated global streams of goods, and while profits from globalization allowed a small portion of society to travel individually and globally, most Germans' mobility was still limited — unlike their favorite detectives. While the bourgeoisie feared mobility as a threat to the status quo, the salaried masses dreamt of a more mobile society. 


\section{Conclusion: The Promise of Mobility and the Realities of Immobility}

The establishment of (locomotive) transportation systems enabled mobility—and enforced immobility. The new experience of sitting still on vehicles and in waiting rooms disrupted ordinary people's participation in social realities; there was nothing to do, little to talk about and even less to engage with visually; all that was left was apprehension. (Of course, there was the possibility of engaging aesthetically with pictorial landscapes, but such an engagement would have required an education few travelers had. ${ }^{68}$ ) In such situations of social and cognitive disengagement, the otherwise idle mind of the traveler, free to expect the worst, is happy to engage in the virtual realities of fictional works. Spectacular forms of fictional mobility seem an appropriate means of making immersion in these virtual realities attractive to the reader: they promise to allow him to forget his social disengagementthrough action. Such spectacular mobility, it appears, can only be imagined in a fictitious 'Anglo-American' realm, one in which the detective can apply his faculties to all emerging situations. The dime novel turns to American and English models and appropriates these to a German context in order to meet the reader's demands. These popular fictions make a promise of mobility, but they address a reality of immobility.

The serial detective is able to appropriate every new situation and investigate whatever case on his own terms in any new context. His mobility, his ability to travel, is a consequence of his appropriative capability. The 'German' detective, physically and technically no less able to travel than the 'Anglo-American' detective, does not do so because he would not be able to appropriate new situations and contexts: his ability to investigate crime is lost in transportation. Mobility infrastructure and the corporeal ability to travel are not enough: the right sensibility, the knowledge that one's capabilities travel inseparably with one's body, is also necessary.

The 'Anglo-American' dime-novel detective is a popular figure of mobility. He uses the infrastructure of travel (trains, autobuses, passenger ships and airplanes) to reach a global variety of crime scenes. Individual forms of mobility (cars, motorbikes, boats, planes) are employed by detectives and criminals to escape or to pursue, respectively. The reader shares the mobility of the detective on the trains both use. But while the detective uses the train to reach his eventful adventures, the reader's mobility is restricted to the train. The reader addressed by dime novels commutes to his workplace, a place characterized by involuntarily physical immobility at the office or on the assembly line. The individualized, unrestricted mobility the detective achieves with cars, boats and planes remains out of reach for the 1920s 
reader. By appropriating detective fiction, German readers learned to appropriate the $\mathrm{im} /$ mobilities resulting from new technologies of transport and communication.

The Nazis, finally, put an end to the Anglicizing of the detective, and to his mobility. In 1935, the Reichsschriftumskammer placed many series on the index, and, when the war began, forbade all Anglicized heroes: Tom Shark becomes Wolf Greif, his sidekick Pitt Strong becomes Peter Strunz; John Kling morphs into Robert Ramm, now assisted by Hans Kiekebusch. ${ }^{69}$ More often than not, they fight against intrusive alien forces in Germany. But even these completely Germanized versions were stopped due to an alleged shortage of paper in $1941 .^{70}$ At the same time, the wane of fictional mobility was met by an increase in individual mobility; the Volkswagen and Autobahn projects changed the landscape of mobility forever; the railway network has been shrinking ever since, while airplane travel has been on the rise since the 1950s - and with it new media as well as new detectives. 
${ }^{1}$ Walter Benjamin, "Travelling with Crime Novels," trans. Aaron Kelly and Martin Harvey, in The Thriller and Northern Ireland since 1969: Utterly Resigned Terror, ed. Aaron Kelly (Aldershot: Ashgate, 2005), 165-166, here: 165.

${ }^{2}$ Heike Weber, "Mobile Electronic Media: Mobile History at the Intersection of Transport and Media History," Transfers 1 no. 1 (2011), 25-49, here: 28.

${ }^{3}$ See Gerard Genette, Paratexts: The Thresholds of Intepretation (Cambridge: CUP, 1997); on the relevance of paratexts for popular literature especially, see Christian Huck, "Was ist Populärliteratur? Oder doch eher, wann ist Populärliteratur?" in Kommunikation im Populären: Interdisziplinäre Perspektiven auf ein ganzheitliches Phänomen, ed. Roger Lüdeke (Bielefeldt: Transcript, 2011), 43-66.

${ }^{4}$ Linda Hutcheon, A Theory of Adaptation (New York: Routledge, 2007), 145-157.

${ }^{5}$ Examining Groschenhefte would have been impossible without the kind hospitality of the Krimimuseum (Butjadingen, Germany); all images are from the collection of Mirko Schädel. ${ }^{6}$ Donna Jeanne Haraway, Simians, Cyborgs, and the Women: The Reinvention of Nature (London: Free Association Books, 1991), 201.

${ }^{7}$ Cf. Karin Littau, Theories of Reading: Books, Bodies and Bibliomania (Cambridge: Polity Press, 2006).

${ }^{8}$ See Christine Haug, Reisen und Lesen im Zeitalter der Industrialisierung. Die Geschichte des Bahnhofs- und Verkehrsbuchhandels in Deutschland von seinen Anfängen um 1850 bis zum Ende der Weimarer Republik (Wiesbaden: Harrassowitz, 2007).

${ }^{9}$ Wolfgang Schivelbusch, The Railway Journey: the Industrialization of Time and Space in the $19^{\text {th }}$ Century (Berkeley: University of California Press, 1987), 130.

${ }^{10}$ Thomas Creevy in 1829; qtd. after Schivelbusch, The Railway Journey, 15.

${ }^{11}$ Schivelbusch, The Railway Journey, 14.

${ }^{12}$ Haug, Reisen und Lesen, 45-49; Schivelbusch, The Railway Journey, 79.

${ }^{13}$ Haug, Reisen und Lesen, 56; Schivelbusch, The Railway Journey, 55, 67.

${ }^{14}$ Littau, Theories of Reading, 161; Haug, Reisen und Lesen, 58; Schivelbusch, The Railway Journey, 64.

${ }^{15}$ See Christine Haug, “'Kriminalromane, auf Reisen’: Kriminal- und Detektiverzählungen als populäre Reiselektüre um 1900," in Zeitdiskurse: Reflexionen zum 19. und 20.

Jahrhundert, ed. Roland Berbig et al. (Heidelberg: Synchron, 2004), 239-257, here: 239.

${ }^{16}$ The main competitors were daily newspapers. Christine Haug, "Ein Buchladen auf Stationen, wo sich zwei Linien kreuzen, müsste gute Geschäfte machen...': Der deutsche Bahnhofs- und Verkehrsbuchhandel von 1850 bis zum Ende der Weimarer Republik im internationalen Vergleich," in Die Internationalität der Eisenbahn, 1850-1970, ed. Monika Burri et al. (Zurich: Chronos, 2003), 71-90; cf. Thomas Bourry, "Medien auf Reisen. Medienformationen für das Reisen mit Eisenbahn, Schiff und Flugzeug" (PhD diss, University of Cologne, 2008), 67, http://kups.ub.uni-koeln.de/2541/ (accessed January 10, 2012).

${ }^{17}$ Katja Schmieder, "Betrachtungen zur Rezeption amerikanischer Kriminalliteratur in Deutschland," in Amerikanische Populärkultur in Deutschland, ed. Katja Kanzler und Heike Paul (Leipzig: Leipziger Universitätskatalog, 2002), 143-66.

${ }^{18}$ Norbert Jacques, "Was ich im Kino nicht mehr sehen möchte," Berliner Illustrierte, June 13, 1920; my translation.

${ }^{19}$ Siegfried Kracauer, From Caligari to Hitler: A Psychological History of the German Film (Princeton: Princeton UP, 1947), 19-20.

${ }^{20}$ Haug, "Ein Buchladen auf Stationen," 72, 84-85. 
${ }^{21}$ See Heinz J. Galle, Populäre Lesestoffe: Groschenhefte, Dime Novels und Penny Dreadfuls aus den Jahren 1850 bis 1950 (Cologne: Kleine Schriften der Universitäts- und Stadtbibliothek Köln, 2002), 29.

${ }^{22}$ Whereas the car is always linked to individual mobility, and trains and coaches to mass travel, planes and boats can be linked to both, depending on their size. Consequently, both trains (Murder on the Orient Express) and passenger ships (Murder on the Nile), and even airships, coaches, yachts and airplanes, lend themselves to classic Golden Age whodunnit crime stories which use the vehicle as an alternative to the traditional secluded country house; cars, small planes and speedboats, on the other hand, are more often used in chase scenes, a typical element of the more action-oriented American tradition. The German crime fiction of the interwar period merges both traditions.

${ }^{23}$ More than an apparent Angstlust, i. e. the thrill of reading about train-related adventures while travelling on board a safe train, the covers of dime novels address the allure of a more general mobility; on Angstlust, see Christine Haug, "Ein Buchladen auf Stationen," 74-76.

${ }^{24}$ From the cover of Edgar Wallace, Überfallkommando. Ein Kriminalroman, trans. Ravi Ravendro (Leipzig: Goldmann, 1930); my translation.

${ }^{25}$ From the banderole on E. Phillips Oppenheim, Scarlett Trent, der Abenteurer, trans. Reinhard Rijke (Berlin: Rijke \& Stock, 1927); my translation.

${ }^{26}$ From the cover of Edgar Wallace, Der Joker. Ein Kriminalroman, trans. Else Baronin Werkmann (Leipzig: Goldmann, 1931); my translation.

${ }^{27}$ From the cover of Edgar Wallace, Das Gesicht im Dunkel, trans. Elise von Kraatz (Leipzig: Goldmann, 1932); my translation.

${ }^{28}$ From the cover of H. L. Rumpff, Die goldenen Schlüssel (Leipzig: Goldmann, 1932); my translation.

${ }^{29}$ Enda Duffy, The Speed Handbook. Velocity, Pleasure, Modernism (Durham: Duke University Press, 2009), 151.

${ }^{30}$ Schivelbusch, Railway Journey, 134-158.

${ }^{31}$ Paul Virilio, Speed and Politics: an Essay on Dromology (New York: Columbia, 1986); cf. Weert Canzler, Vincent Kaufmann and Sven Kesselring, "Tracing Mobilities - An Introduction," in Tracing Mobilities: Towards a Cosmopolitan Perspective, ed. Weert Canzler, Vincent Kaufmann and Sven Kesselring (Aldershot: Ashgate, 2008), 1-10.

${ }^{32}$ Duffy, The Speed Handbook, 3.

${ }^{33}$ Schivelbusch, Railway Journey, 16.

${ }^{34}$ Michel de Certeau, The Practice of Everyday Life (London: University of California Press, 1984), 111-14; cf. Nigel Thrift, Non-representational Theory: Space, Politics, Affect (New York: Routledge, 2008), 78-9.

${ }^{35}$ Rainer Paris, "Warten auf Amtsfluren," Kölner Zeitschrift für Soziologie und Sozailpsychologie 53 no. 4 (2001), 705-733, here: 707.

${ }^{36}$ de Certeau, The Practice of Everyday Life, 111.

${ }^{37}$ Paris, "Warten auf Amtsfluren," 708-13.

${ }^{38}$ Canzler, Kaufmann and Kesselring, "Tracing Mobilities," 4.

${ }^{39}$ Kaspar Maase, "Die soziale Bewegung gegen Schundliteratur im deutschen Kaiserreich. Ein Kapitel aus der Geschichte der Volkserziehung," Internationales Archiv für Sozialgeschichte der deutschen Literatur 27 no. 2 (2002), 45-123.

${ }^{40}$ In the larger cities of the Weimar Republic, white-collar workers made up about forty percent of the work force. Anthony McElligott, "Per Fahrrad, Bus und Bahn. Angestellte unterwegs," in Großstadtmenschen. Die Welt der Angestellten, ed. Burkhart Lauterbach (Frankfurt/Main: Büchergilde Gutenberg, 1995), 126-39, here: 129. 
${ }^{41}$ Lynda K. King, Best-Sellers by Design: Vicki Baum and the House of Ullstein (Detroit: Wayne State UP, 1988), 33. For this reason I use only the masculine form when referring to readers.

${ }^{42}$ McElligott, "Per Fahrrad, Bus und Bahn," 127; Burkhart Lauterbach, "Der Weg zur Arbeit," in Großstadtmenschen. Die Welt der Angestellten, ed. Burkhart Lauterbach (Frankfurt/Main: Büchergilde Gutenber, 1995), 117-24, here: 124.

${ }^{43}$ Christoph Kopper, Handel und Verkehr im 20. Jahrhundert, Enzyklopädie Deutscher Geschichte, vol. 63 (München: Oldenbourg, 2002).

${ }^{44}$ Ulrich Kluge, Die Weimarer Republik (Paderborn: Schöningh, 2006), 240.

${ }^{45}$ The bibliographic information has been compiled on the basis of Mirko Schädel's llustrierte Bibliographie der Kriminalliteratur, 1796-1945, im deutschen Sprachraum, 2 vols. (Butjadingen: Achilla, 2006).

${ }^{46}$ From the cover of Louis Vetter, Unheimliche Gegner (Berlin: Auffenberg, 1935); my translation.

${ }^{47}$ Genette, Paratexts, 18; my emphasis; cf. Bourry, "Medien auf Reisen," 65.

${ }^{48}$ The development in Germany followed suit; cf. Heinrich Keiter and Tony Kellen, Der Roman. Theorie und Technik des Romans und der erzählenden Dichtung, nebst einer geschichtlichen Einleitung, 4th ed. (Essen-Ruhr: Fredebeul \& Koenen, 1912), 189.

${ }^{49}$ Cf. Heinz J. Galle, Groschenhefte. Die Geschichte der deutschen Trivialliteratur (Frankfurt/Main: Ullstein, 1988), 53.

${ }^{50}$ See Werner G. Schmidtke, "Sherlock Holmes auf der Hintertreppe: Die Kriminalerzählung im deutschen Heftroman," in Sherlock Holmes auf der Hintertreppe: Aufsätze zur

Kriminalliteratur, ed. Werner G. Schmidtke and Armin Arnold (Bonn: Bouvier, 1981), 7-81, here: $19-21$.

${ }^{51}$ The detective also becomes an anthropomorphized doppelganger of the ten-cent coin that gave its name to the publication to which he is native: the dime novel-like money, the dime novel detective was able to transcend the ties of land and labor; see Christian Huck, "The Total Mobility of the Dime Novel Detective," in Mobilities, Movements and Metaphors, ed. Christoph Ehland et al. (Amsterdam/New York: Rodopi), forthcoming.

${ }^{52}$ Gary Hoppenstand, "Introduction. The Missing Detective," in The Dime Novel Detective, ed. Gary Hoppenstand (Bowling Green, Ohio: Bowling Green University Popular Press, 1982), 3-4.

${ }^{53}$ Susan Danly, "Introduction," in The Railroad in American Art: Representations of Technological Change, ed. Susan Danly and Leo Marx (Cambridge, Mass.: MIT Press, 1988), 1-50, here: 16 .

${ }^{54}$ See J. Randolph Cox, “The Paperback Detective: The Evolution of the Nick Carter Series from Dime Novel to Paperback, 1886-1990," in Pioneers, Passionate Ladies and Private Eyes, ed. Larry E. Sullivan and Lydia Cushman (New York: Haworth Press, 1996), 119-131, here: 121; E. F. Bleiler, "Introduction," in Eight Dime Novels, ed. E. F. Bleiler (New York, Dover, 1974), vii-xv.

${ }^{55}$ See Rimmer Sterk and Jim Conkright, The Continental Dime Novel (JCRS, 2006), 62-72.

${ }^{56}$ On the 'localization' of literary genres, see Takeshi Matsui, "The Diffusion of Foreign Cultural Products: The Case Analysis of Japanese Comics (Manga) Market in the US," Princeton University: Center for Arts and Cultural Policy Studies, Working Paper Series 37 (2009), http://www.princeton.edu/ artspol/workpap/WP37-Matsui.pdf (accessed on 05.06.2011).

57 [Pitt Strong], Das Rätsel um Alice Amerong, Tom Shark der König der Detektive, no. 120 (Heidenau: Freya, n. d.); my translation. 
${ }^{58}$ Dorit Müller, "Transfers between Media and Mobility: Automobilism, Early Cinema, and Literature, 1900-1920," Transfers 1 no. 1 (2011), 50-72.

${ }^{59}$ See Werner G. Schmidtke, Der letzte König von Berlin: Zur Heftserie 'Tom Shark' (Siegen: MUK, 1981), 22.

${ }^{60}$ Kracauer, From Caligari to Hitler, 19-20.

${ }^{61}$ See Hans-Otto Hügel, Untersuchungsrichter, Diebsfänger, Detektive. Theorie und Geschichte der deutschen Detektiverzählung im 19. Jahrhundert (Stuttgart: Metzler, 1978).

${ }^{62}$ Mathilde Kelchner and Ernst Lau, Die Berliner Jugend und die Kriminalliteratur: Eine Untersuchung aufgrund von Aufsätzen Jugendlicher, Beihefte zur Zeitschrift für angewandte Psychologie, vol. 42 (Leipzig: Barth, 1928), 19-28.

${ }^{63}$ See Knut Hickethier and Wolf Dieter Lützen, "Der Kriminalroman. Entstehung und Entwicklung eines Genres in den literarischen Medien," in Trivialliteratur, ed. Annamaria Rucktäschl and Hans Dieter Zimmermann (Munich: Fink, 1976), 267-295, here: 275.

${ }^{64}$ Cf. Peter Berg, Deutschland und Amerika 1918-1929: über das deutsche Amerikabild der Zwanziger Jahre (Lübeck: Matthiesen, 1963), 134-36.

${ }^{65}$ Siegfried Kracauer, Der Detektiv-Roman. Ein philosophischer Traktat (Frankfurt/Main: Suhrkamp, 1979), 82; my translation.

${ }^{66}$ Adelheid von Salder, "Überfremdungsängste. Gegen die Amerikanisierung der deutschen Kultur in den zwanziger Jahren," in Amerikanisierung: Traum und Alptraum im Deutschland des 20. Jahrhunderts, ed. Alf Lüdtke et al. (Stuttgart: Franz Steiner, 1996), 213-44; Michael Wala, "Amerikanisierung und Überfremdungsängste: Amerikanische Technologie und Kultur in der Weimarer Republik," in Technologie und Kultur: Europas Blick auf Amerika vom 18. bis zum 20. Jahrhundert, ed. Michael Wala and Ursula Lehmkuhl (Köln: Böhlau, 2000), 12146.

${ }^{67}$ On the life of the 'salaried masses,' see Siegfried Kracauer, Die Angestellten. Eine Schrift vom Ende der Weimarer Republik (Allensbach: Verlag für Demoskopie, 1959 [1930]).

${ }^{68}$ Cf. Mitchell Schwarzer, Zoomscape: Architecture in Motion and Media (Princeton: Princeton Architectural Press, 2004), 46-56.

${ }^{69}$ Galle, Groschenhefte, 121.

${ }^{70}$ Schmidtke, "Sherlock Holmes auf der Hintertreppe“, 16. 